\title{
Standardowe i niestandardowe zachowania językowe lekarzy i pacjentów. Propozycja projektu badawczego
}

\section{Standard and nonstandard linguistic behaviours of the doctor - patient communication. The proposal of a research project}

\section{Streszczenie:}

Celem artykułu jest omówienie projektu badawczego dotyczącego komunikacji lekarza z pacjentem $w$ realnych sytuacjach z perspektywy teorii aktów mowy. Intencją autora jest pokazanie możliwości badań standardowych i niestandardowych zachowań językowych lekarzy i pacjentów. Relacja lekarz pacjent jest jednym z najistotniejszych elementów efektywnego procesu leczenia. Przekaz informacji pacjentowi powinien być ukierunkowany i dostosowany do specyficznej grupy chorych i indywidualnego człowieka. Jakość kontaktu pomiędzy chorym a osobą leczącą, ma istotne znaczenie w procesie zdrowienia. Zwiększenie roli pacjenta $w$ procesie diagnozy i leczenia jest obecne w założeniach jeszcze bardziej kompleksowego podejścia do zdrowia.

Słowa kluczowe: lekarz, pacjent, komunikacja, organizacja opieki medycznej, akt mowy

\begin{abstract}
:
The aim of the article is to discuss a research project on doctor - patient communication in real-life situation from the perspectives of the speech act theory. The intention of the author is to show and characterize the standard
\end{abstract}


Michał Chojnowski - Standardowe i niestandardowe...

and nonstandard linguistic behaviours of the doctor - patient communication. The ability to communicate with patients is an important element of effective therapy. Information with patients receive should be focused and adjusted to both the particular patient group and the individual recipient. The quality of a relationship between physician and patient is vital to recovery from illness. Increasing the role of the patient in the process of the diagnosis and the treatment is present in the design of the diagnosis and the treatment is present in the design of more comprehensive approach to health.

Keywords: doctor, patient, communications, organization of medical care, act speech

\section{Wstęp}

Niniejszy artykuł poświęcony jest projektowi badawczemu, który autor zamierza realizować i dotyczy wybranych aspektów relacji interpersonalnych lekarza z pacjentem z uwzględnieniem stosowanych strategii komunikacyjnych z perspektywy zachowań standardowych i niestandardowych, które ujawniają się w codziennych sytuacjach komunikacyjnych w gabinecie lekarskim. Pojęcie zachowań standardowych obejmuje zachowania werbalne mieszczące się z obrębie podstawowego wzoru rozmowy lekarza z pacjentem. Natomiast zachowania niestandardowe ujawniają się w praktycznych realizacjach rozmowy modelowej w gabinecie lekarskim zarówno w doborze treści, jak i realizacji środków językowych.

Artykuł składa się z kilku części. Omówiona w nim zostanie rola relacji interpersonalnych lekarza z pacjentem. Następnie zostaną wskazane modele komunikowania się lekarza z pacjentem, scharakteryzowana cecha asymetrii dla sytuacji wizyty chorego $\mathrm{w}$ gabinecie lekarskim oraz omówiony standardowy wzorzec rozmowy w gabinecie lekarskim. Podczas zbierania materiału badawczego i rejestracji dialogów lekarza z pacjentem ujawniły się modyfikacje tego modelu realizujące się w praktyce. Zostaną zatem zaproponowane założenia projektu badawczego w zakresie komunikowania się lekarza z pacjentem 
i stosowanych $\mathrm{w}$ tym obszarze strategii konwersacyjnych z uwzględnieniem teorii aktów mowy w celu wskazania możliwości odstępstwa od modelowej rozmowy w ramach praktycznej realizacji modelu i stosowanych wówczas strategii z przypisanymi do nich aktami mowy.

\section{Uzasadnienie wyboru tematu}

Do podjęcia aktywności w obszarze badań komunikacji lekarza z pacjentem zainspirowało mnie kilka czynników. Pierwszym z nich jest charakter współczesnego leczenia, w którego ramach sposób komunikowania się lekarza z pacjentem ma wpływ na przebieg leczenia. W medycynie zawiera się bowiem nie tylko element nauki i technologii, ale i realizacja więzi międzyludzkich. $Z$ jednej strony w procesie wymiany informacji występuje lekarz, który przekazuje informację jako wypadkową kompetencji zawodowych, tj. kwalifikacji potrzebnych do wykonywania zawodu lekarza, a także kompetencji komunikacyjnych i narracyjnych (umiejętność okazywania empatii, rozumienia emocji itp.). Z drugiej strony występuje pacjent, który jest nie tylko klientem i odbiorcą usług medycznych, ale i człowiekiem znajdującym się w trudnym i nieakceptowanym przez siebie położeniu i zwraca się do lekarza ze swoim problemem, okazuje mu zaufanie i powierza swoje zdrowie.

Drugim z czynników, które miały wpływ na podjęcie aktywności w tym obszarze, jest brak zainteresowań lingwistów relacjami interpersonalnymi lekarza z pacjentem w porównaniu z zainteresowaniem socjologów, psychologów i samych lekarzy. Całościowy obraz relacji interpersonalnych lekarza z pacjentem to rezultat zestawienia wyników badań nie tylko w zakresie medycyny, ale także socjologii i psychologii. Badania prowadzone w każdej z tych dziedzin nie tylko dają inne rezultaty, ale i uzupełniają się nawzajem. Już w latach 60 . ubiegłego wieku badacze podkreślali, że postawienie diagnozy i wyznaczenie procesu leczenia to efekt nie tylko stosowania medycznych procedur, ale i sposobu rozmowy z pacjentem. Podejście medyczne 
Michał Chojnowski - Standardowe i niestandardowe...

w badaniu tych relacji koncentruje się na kwestii choroby. Podejście psychologiczne natomiast - na kontakcie lekarza z pacjentem jako na układzie interpersonalnym. Inaczej sytuacja przedstawia się $\mathrm{w}$ badaniach socjologicznych, w których badane są relacje przebiegające według wzorców w kontekście ogólnego systemu społecznego. Problematyka relacji lekarz - pacjent znalazła odzwierciedlenie w pracach naukowców socjologii medycyny, Współcześnie socjologia medycyny subdyscyplina socjologii i nauka współpracująca z medycyną ugruntowała swoją pozycję koncentrując się wokół problematyki dotyczącej udzielania praktycznych wskazówek w kwestii prowadzenia skutecznej komunikacji z pacjentem. Wiele prac z tego zakresu dotyczy również ujęcia psychologicznego i pedagogicznego. W centrum uwagi pozostaje przede wszystkim pacjent, ale również badana jest dysfunkcjonalność systemu ochrony zdrowia ${ }^{1}$.

Brak jednak rozbudowanego ujęcia lingwistycznego tego obszaru, które dopełniłoby całościowy obraz relacji lekarz - pacjent. Badania lingwistyczne - które będą opisane poniżej - miałyby dać odpowiedź na pytanie o stosowanie strategii konwersacyjnych w rozmowie lekarza z pacjentem gwarantujących skuteczność komunikacji. Chociaż wydawałoby się, że badania lingwistyczne tego typu powinny być rozwijane, nie dzieje tak, chociażby z powodu trudności uzyskania materiału badawczego. Jedyna w Polsce książka, której autorka bada relacje interpersonalne między lekarzem a pacjentem to książka Karoliny Stefaniak Władza i tożsamość w komunikacji lekarz - pacjent ${ }^{2}$. Autorka opiera swoje wnioski na materiale 40 nagrań z konsultacji lekarskich w okresie 2005-2007 nagranych w Warszawie. Po 10 latach od czasu badań przeprowadzonych przez Karolinę Stefaniak wydaje się zasadne przeprowadzenie badań na podstawie nagranych rozmów lekarzy

${ }^{1}$ A. Ostrowska, Zachowania zdrowotne Polaków na poczq̨tku XXI wieku, [w:] Polska początku XXI wieku. Przemiany kulturowe i cywilizacyjne, K. Frysztacki, P. Sztompka (red.), Warszawa 2012, s. 356-365; A. Titkow, Zachowania zwiq̨zane ze zdrowiem i chorobq jako element wiedzy o społeczeństwie [w:] Socjologia medycyny. Podejmowane problemy, kategorie analizy, A. Ostrowska (red.), Warszawa 2009, s. 87-113.

2 K. Stefaniak, Władza i tożsamość w komunikacji lekarz - pacjent, Wrocław 2011. 
z pacjentami. Proponowana jest jednak inna metodologia, niż przyjęła autorka wskazanej książki³ , a mianowicie analiza strategii konwersacyjnych ze wskazaniem stosowanych przez rozmówców strategii konwersacyjnych i poprzez strategie - realizację aktów mowy. B. Boniecka w artykule Niestandardowe zachowania językowe lekarzy i pacjentów wskazuje, jak w naturalnych sytuacjach życiowych łamany jest podręcznikowy wzór rozmowy miedzy pacjentem i lekarzem w sytuacji wizyty chorego $\mathrm{w}$ gabinecie lekarskim na podstawie 30 jednostek tekstowych ${ }^{4}$.

Kolejny czynnik, który spowodował zainteresowanie tematem, to koncentrowanie się lingwistów na analizie tekstów o charakterze edukacyjno-informacyjnym lub na przekładach terminologii medycznej. Wymienić można np. artykuły Anny Starzec Charakterystyka genologiczna i stylistyczna ulotki medycznej5 oraz Ulotka medyczna i jej przemiany6; Jana Iluka Problemy tłumaczenia nazw medycznych na przykładzie języka polskiego ${ }^{7}$ oraz książkę Urszuli Kokot Metody przekładu niemieckich nazw medycznych na język polski ${ }^{8}$. Ukazuje się przy tym wiele poradników wskazujących prowadzenie właściwej i skutecznej komunikacji i skierowane są do lekarzy, np. Poradnik komunikowania się lekarza z pacjentem $^{9}$; Jak rozmawiać z pacjentem ${ }^{10}$; Rozmawiać

\footnotetext{
${ }^{3}$ Autorka wykorzystała metody jakościowe: krytyczną analizę dyskursu i analizę konwersacji.

4 B. Boniecka, Niestandardowe zachowania językowe lekarzy i pacjentów, „Poznańskie Spotkania Językoznawcze” 2004, Tom XIII, s. 7-25. Rozmowy odbywały się między pacjentami a lekarzami oraz personelem medycznym w izbie przyjęć pewnego pogotowia ratunkowego w Małopolsce.

${ }^{5}$ A. Starzec, Charakterystyka genologiczna i stylistyczna ulotki, [w:] Język a komunikacja 17: Język polski XXI wieku: analizy, oceny, perspektywy, G. Szpila (red.), Kraków 2007, s. 165-174.

${ }^{6}$ A. Starzec, Ulotka medyczna i jej przemiany, „Stylistyka” 2007, nr 16, s. 519-529.

7 J. Iluk, Problemy tłumaczenia nazw medycznych na przykładzie języka polskiego i niemieckiego, „Glottodidactica” 1998, nr 26, s. 123-136.

${ }^{8} \mathrm{U}$. Kokot, Metody przekładu niemieckich nazw medycznych na język polski, Katowice 2001.

9 M. Hebanowski, J. Kliszcz, B. Trzeciak, Poradnik komunikowania się lekarza z pacjentem, Warszawa 1999.

10 P. R. Mayerscough, M. Ford, Jak rozmawiać z pacjentem, Gdańsk 2002.
} 
Michał Chojnowski - Standardowe i niestandardowe...

z pacjentem ${ }^{11}$. Pojawiają się także poradniki skierowane do pacjentów, np. Jak rozmawiać z lekarzem ${ }^{12}$; Świadomy pacjent. Jak mówić, żeby lekarz Cię słuchał13. Wśród poradników skierowanych do obu uczestników interakcji wymienić można przykładowo Komunikowanie się lekarza z pacjentem ${ }^{14}$.

Wskazanie podręczników, które w sposób modelowy charakteryzują komunikację lekarza $\mathrm{z}$ pacjentem, jest punktem wyjścia do sformułowania kolejnego czynnika, determinującego celowość badań w tym zakresie. Chodzi o zróżnicowanie pomiędzy modelowym przedstawieniem relacji lekarza z pacjentem poprzez prezentacje wzorów rozmów a rozmowami odbywającymi się podczas wizyty lekarskiej, które nie uwzględniają tych standardów, przy wskazaniu zachowań werbalnych obu interlokutorów ${ }^{15}$. Dodać należy, iż zagadnieniom komunikowania się lekarza z pacjentem na świecie od ponad dwudziestu pięciu lat poświęca się wiele uwagi. Wymienić w tym miejscu należy miedzy innymi autorów: A. J. Enelow, S. N. Swisher, H. Waitzkin, D. Pendleton, J. Hasler, M. Cordella, E. G. Mishler'16.

11 T. Gordon, W. S. Edwards, Rozmawiać z pacjentem: podręcznik doskonalenia umiejętności komunikacyjnych i budowania partnerskich relacji, Warszawa 2009.

12 P. Grabowski, E. Lutczyn, Jak rozmawiać z lekarzem. Warszawa 2012.

13 B. M. Korsch, C. Harding C., Świadomy pacjent. Jak mówić, żeby lekarz Cię słuchał, Warszawa 1999.

${ }^{14}$ J. Barański, E. Waszyński, A. Steciwko (red.), Komunikowanie się lekarza z pacjentem, Wrocław: Wydawnictwo Astrum 2000.

15 Pomijam kwestię zachowań niewerbalnych, gdyż wymagałoby to odrębnych badań. Zresztą ujęcie strategii dyskursywnych nie odwołuje się do pozawerbalnej strony komunikacji. Zob.: J. Labocha, Tekst, wypowiedź, dyskurs, [w:] Styl a tekst, S. Gajda (red.), Opole 1996, s. 49-53; M. Wojtak, Strategie dyskursywne w pewnym typie tekstu dydaktycznego, [w:] Język w komunikacji, G. Habrajska (red.), Łódź 2001, s. $168-178$.

16 A. J. Enelow, S. N. Swisher, S. N., Interviewing and patient care, New York 1986; D. Pendleton, J. Hasler (red.), Doctor - patient communication. New York 1983; H. Waitzkin, Doctor - patient communication: Clinical implications of social scientific research, "Journal of The American Medical Association” 1984, Vol. 252, s. 2441-2446; M. Cordella, The Dynamic Consultation: A Discourse Analytical Study of Doctor - Patient Communication. Amsterdam/Philadelphia 2004; E. G. Mishler, The Discource of Medicine: Dialectics of Medical Interviews. Norwood 1984. 
Podkreślić należy, iż badania lingwistyczne stawiają przed sobą inne cele, niż badania socjologiczne czy psychologiczne i stosują inne podejścia badawcze. Dlatego też wydaje się celowe uzupełnienie luki w zakresie badań lingwistycznych komunikowania się lekarza z pacjentem ze wskazaniem stosowanych strategii konwersacyjnych z perspektywy teorii aktów mowy. Przebieg i językowy kształt rozmowy jest rezultatem świadomej strategii dominującego uczestnika, moderatora - lekarza, co nadaje komunikacji charakter asymetryczny. Umiejętność budowania pozytywnych relacji interpersonalnych jest przy tym warunkiem sukcesu komunikacyjnego lekarza z pacjentem. Zaburzenie równowagi komunikacyjnej nie sprzyja bowiem budowaniu właściwej relacji, co ma wpływ na efekty leczenia, gdyż charakter komunikacji interpersonalnej wpływa nie tylko na zadowolenie pacjentów z kontaktów z personelem medycznym, ale przede wszystkim na sam proces leczenia.

Autor i wykonawca projektu podda zatem badaniu rzeczywisty przebieg komunikacji lekarza z pacjentem na podstawie rejestrowania materiału badawczego podczas konsultacji w gabinecie lekarskim. Na podstawie wyników badań z wykorzystaniem teorii aktów mowy w ramach komunikowania się lekarza z pacjentem, będzie możliwa odpowiedź między innymi na pytania:

- Jakie są ogólne aspekty komunikowania się lekarza z pacjentem?

- W jaki sposób asymetria instytucjonalna odzwierciedla się w asymetrii interakcyjnej?

- Jak podnieść efektywność relacji lekarz - pacjent?

- Jak radzić sobie z emocjami w czasie rozmowy?

- Jak prowadzić rozmowę z pacjentami w różnym wieku (dziecko, wiek średni, senior)?

- Jak reagować na agresję werbalną pacjenta?

- Jak nakłaniać niedyrektywnie? Jakich strategii językowych używać, aby osiągnąć cel komunikacyjny? 
Michał Chojnowski - Standardowe i niestandardowe...

\section{Modele komunikowania się lekarza z pacjentem}

W oparciu o literaturę przedmiotu można wyróżnić kilka modeli komunikowania się lekarza z pacjentem, a wśród nich:

- model paternalistyczny Talcotta Parsonsa ${ }^{17}$ (pozycja lekarza i pacjenta są ze sobą sprzężone przy asymetrycznym układzie),

- model Thomasa Szasza i Marca Hollendera ${ }^{18}$ o charakterze paternalistycznym,

- model Eliota Freidsona oraz Howarda Waitzkina ${ }^{19}$ oparty na teorii konfliktu,

- koncepcja Ezekiela J. Emanuel and Lindy L. Emanuel20 proponująca wyróżnienie czterech modeli relacji lekarza z pacjentem: model paternalistyczny, model informacyjny, model interpretacyjny oraz model deliberacyjny.

W modelu Talcotta Parsonsa pozycja lekarza i pacjenta są ze sobą sprzężone w układzie asymetrycznym z dominującą pozycją lekarza, który ustala autorytatywnie terapię i ją prowadzi, wiedząc, co jest najlepsze dla pacjenta. Przedmiotem terapii nie jest osoba, lecz choroba. Pacjent wykazuje pełną gotowość do podporządkowania się wymogom leczenia.

Z kolei w modelu Thomasa Szasza i Marca Hollendera, również o charakterze paternalistycznym, wyróżniono 3 rodzaje interakcji, które są uzależnione od stanu chorego: aktywność - bierność, kiero-

17 T. Parsons T.,The Social System. London 1951; Tegoż: Social Structure and Personality. New York 1964.

18 T. Szasz, M. H. Hollender, A contribution to the philosophy of medicine: the basic models of the doctor - patient relationship. „Archives of Internal Medicine” 1956, nr 97, s. 585-592.

${ }^{19}$ E. Freidson, Profession of Medicine: A Study of the Sociology of Applied Knowledge, New York 1970; H. Waitzkin, A critical theory of medical discourse. Ideology, social control and the processing of social context in medical encounters. "Journal of Health and Social Behaviour" 1989, nr 30, s. 220-239.

${ }^{19}$ H. Waitzkin H., A critical theory..., dz.. cyt.

20 E. J. Emanuel, L. L. Emanuel, Four models of physician - patient relationship, „Journal American Medical Association” 1992, nr 16, s. 5-13. 
wanie - współpraca, współuczestnictwo. Pierwszy rodzaj interakcji (aktywność - bierność) ma miejsce wówczas, kiedy pacjent jest nieprzytomny lub pod narkozą, a działania lekarza odbywają się niezależnie od pacjenta. Natomiast rodzaj interakcji kierowanie - współpraca ma miejsce wówczas, kiedy lekarz wydaje polecenia, a pacjent je wykonuje. W rodzaju interakcji nazwanym współuczestnictwem, chory prowadzi leczenie sam, konsultuje się przy tym z lekarzem okresowo.

W modelach paternalistycznych opartych na teorii konfliktu Eliota Freidsona oraz Howarda Waitzkina relacja lekarza z pacjentem jest uwarunkowana różnicami ich interesów oraz różnicą pozycji w strukturze społecznej. Lekarz zajmuje pozycje dominującą z powodów sprawowania kontroli nad dostępem do wszystkich świadczeń medycznych. Konflikt lekarza z pacjentem dotyczy konfliktu między korzyściami materialnymi, a w interesie lekarza leży zachowanie niedostępności wiedzy dla innych oraz oceny działalności.

Modele partnerskie rozpatrują relację lekarza z pacjentem z punktu widzenia konsumenta usług medycznych, czyli pacjenta, w której lekarz jest doradcą i współdecydentem. Podkreśla się aktywność pacjenta, który wybiera lekarza oraz alternatywne źródła pomocy, pacjent również ocenia rezultaty działań lekarza. Z kolei w modelu opartym na promocji zdrowia lekarz jest doradca, posiada autorytet, pełni rolę wspierającą i zajmuje się promocja zdrowia.

Ezekiel J. Emanuel and Linda L. Emanuel proponują wyróżnienie czterech modeli relacji lekarza z pacjentem: model paternalistyczny, w którym lekarz przejmuje rolę decydenta, określając, co jest najlepsze dla pacjenta, także w kontekście najodpowiedniejszego sposobu leczenia, model informacyjny, który opiera się na wiedzy eksperckiej lekarza profesjonalisty, który dostarcza informacje pacjentowi, a pacjent sam dokonuje wyboru metod leczenia, model interpretacyjny związany jest z pełnieniem przez lekarza roli doradcy, który uwzględnia preferencje pacjenta oraz pomaga mu zrozumieć, jakie wartości leżą u podstaw jego decyzji. Z kolei w ramach modelu deliberacyjnego 
Michał Chojnowski - Standardowe i niestandardowe...

odbywa się wspólne naradzanie się lekarza z pacjentem, w oparciu o doświadczenia zawodowe lekarza, w celu wybory najbardziej odpowiedniego modelu leczenia.

Niektórzy badacze wychodzą z założenia, iż modele komunikowania się lekarza z pacjentem są zbyt teoretyczne, nie dotyczą rzeczywistych problemów, ograniczają się wyłącznie do informacji lekarskich, sztywno klasyfikują relacje lekarza z pacjentem, nie obejmują codziennych problemów pacjenta związanych $\mathrm{z}$ pogorszeniem stanu zdrowia ${ }^{21}$.

\section{Komunikacja lekarza z pacjentem jako relacja asymetryczna}

Konsultacja lekarska - jako specyficzny akt komunikacji - zachodzi $\mathrm{w}$ warunkach instytucjonalnych między osobami pozostającymi w relacji asymetrii, która może zaznaczać się w większym lub mniejszym stopniu $^{22}$. Asymetria komunikacyjna przejawia się poprzez rożny status społeczny rozmówców, zróżnicowaną pozycję w hierarchii społecznej, zróżnicowany poziom wiedzy uczestników komunikacji. Z jednej strony bowiem jest to pacjent potrzebujący pomocy, z drugiej strony lekarz posiadający specjalistyczną wiedzę i doświadczenie. Jeśli pacjent przychodzi do lekarza pierwszego kontaktu, którego dobrze zna, to poziom asymetrii jest najmniejszy. Natomiast, kiedy pacjent przychodzi do lekarza specjalisty, asymetria komunikacyjna zaznacza się w największym stopniu. Kolejnym czynnikiem determinującym asymetrię komunikacyjną jest wiek, np. asymetryczna jest komunikacja dorosłego z dzieckiem, kiedy dorosły realizuje inicjatywne akty mowne w niektórych fragmentach rozmowy kilkakrotnie. Inaczej lekarz będzie rozmawiał z dzieckiem, inaczej z osobą dorosłą, a jeszcze inaczej z osobą starszą. Relacja między lekarzem a pacjen-

${ }^{21}$ G. Clarke, R. Hall, G. Rosencrance, Physician - Patient Relations: No More Models, „American Journal of Bioethics” 2004, nr 2, s. 16-19.

22 O symetryczności i asymetryczności komunikacji m. in. I. Prokop, Aspekty analizy pragmalingwistycznej. Poznań 2010, s. 16. 
tem wyznacza między nimi dystans społeczny. Pozycja społeczna wyznaczona jest poprzez zajmowane stanowisko, wykształcenie, ale i prestiż społeczny Pozycja społeczna jest to miejsce jednostki w grupie społecznej, z którym związane są prawa i obowiązki, zespół określonych ról społecznych, jakie jednostka może pełnić w grupie ${ }^{23}$. Dominacja w rozmowie przejawia się poprzez używanie przez interlokutora dominującego leksemów o zwiększonej kategoryczności, ograniczających swobodę odbiorcy, honoryfikatywnych (grzecznościowych) oraz tych, które wyrażają sprawczość24. Pacjenci sami dążą do zmniejszenia poziomu asymetrii poprzez np. przygotowanie się do rozmowy z lekarzem, czerpiąc chociażby informacje z Internetu na temat chorób, a informacje te zamieszczane są przecież nie zawsze przez uprawnione do tego osoby.

A zatem na poziom asymetrii w relacji lekarz - pacjent mają wpływ między innymi czynniki związane z osobami lekarza i pacjenta. Do nich należy np. wiek lekarza, relacja między wiekiem lekarza, a wiekiem pacjenta, płeć lekarza, specjalizacja lekarza (zwiększenie poziomu asymetrii w przypadku lekarza-specjalisty) oraz związane z nią cel wizyty pacjenta, częstość kontaktów (zróżnicowanie relacji z lekarzem pacjentów przewlekle chorych, pacjentów konsultujących się stale z tym samym specjalistą, pacjentów na ostrym dyżurze), obecność osób trzecich podczas rozmowy, zarówno ze strony lekarza (inny lekarz, personel medyczny, student, tłumacz), jak i ze strony pacjenta (członek rodziny, rodzice dziecka, tłumacz), faza konsultacji, miejsce konsultacji (szpital, przychodnia, wizyta lekarza w domu pacjenta).

\footnotetext{
23 J. Lyons, Semantyka, t. I, Warszawa 1989, s. 191.

24 J. Wasilewski, Retoryka dominacji, Warszawa 2006, s. 124.
} 
Michał Chojnowski - Standardowe i niestandardowe...

\section{Elementy standardowej rozmowy lekarza z pacjentem}

Standardowa rozmowa lekarza z pacjentem zawiera następujące działania werbalne uczestników interakcji25:

1. Wezwanie (zaproszenie) do gabinetu skierowane przez lekarza do pacjenta (np. Proszę!; Proszę wejść!; Pani Kowalska!);

2. Działania powitalne inicjowane przez pacjenta (zwykle: Dzień dobry, pani doktor/panie doktorze - Dzień dobry pani/ panu);

3. Zachęta skierowana do pacjenta, by ten zajął miejsce (zwykle: Proszę usiąść; Proszę, niech pan siądzie);

4. Zachęta skierowana do pacjenta, by ten przedstawił nurtujący go problem (np. Słucham pania/pana; Co pani/panu dolega? Co się dzieje?);

5. Wyliczenie i opis dolegliwości dokonane przez pacjenta (np. Panie doktorze, od jakiegoś czasu odczuwam bóle w kolanie, zwłaszcza jak wchodzę po schodach);

6. Wywiad z pacjentem (mniej lub bardziej szczegółowy) prowadzący do zdiagnozowania pacjenta przez lekarza (np. Czy gardło pana boli; Kaszle pan?);

7. Deklarowanie przez lekarza zbadania pacjenta (np. Teraz zmierze panu ciśnienie; Proszę szeroko otworzyć usta);

8. Poinformowanie pacjenta o zakończeniu badania (Dziękuję, może się pan ubrać);

9. Poinformowanie pacjenta o stanie jego zdrowia, postawienie diagnozy, zaordynowanie leków i zalecenie postepowania leczniczego (np. Serce w porzq̨dku, płuca też. Niestety - grypa. Proszę brać te lekarstwa; Zapisałem panu na kartce, ile razy dziennie, który lek. Proszę leżeć w łóżku, dużo pić, nie męczyć wzroku. Dostanie pan zwolnienie pracy na siedem dni. Proszę się pokazać u mnie za tydzień);

${ }^{25} \mathrm{Na}$ podstawie artykułu B. Bonieckiej: Niestandardowe zachowania językowe lekarzy i pacjentów... oraz A. Markowskiego: Kultura języka w porozumiewaniu się lekarza z pacjentem [w:] Porozumienie z pacjentem. Relacje i komunikacja, J. Doroszewski, M. Kulus, A. Markowski, (red.), Warszawa 2014, s. 85-88. 
10. Pytania dodatkowe ze strony pacjenta, który chce uzyskać dodatkowe informacje (np. Jak długo będę jeszcze miał gorączkę? Czy muszę leżeć, czy mogę chodzić po mieszkaniu?);

11. Dodatkowe wyjaśnienia lekarza; także przekazanie elementów koncyliacyjnych (np. Myślę, że za trzy dni goraczka powinna ustapić. Proszę się nie martwić, po tych lekach powinna szybko nastąpić poprawa);

12. Wyrażenie podziękowania ze strony pacjenta (np. Dziękuję, panie doktorze!);

13. Działania pożegnalne - inicjowane przez lekarza lub pacjenta (Życzę panu zdrowia, do widzenia panu - Do widzenia, panie doktorze).

\section{Strategie konwersacyjne w rozmowie lekarza z pacjentem}

\section{Cel projektu}

Głównym celem projektu będzie analiza modyfikacji modelowego sposobu komunikowania się lekarza z pacjentem z formalnego i treściowego punktu widzenia. Punktem wyjścia będzie „podręcznikowy” model komunikacji lekarz - pacjent, który przytaczany jest w podręcznikach wskazujących idealną sytuację komunikacyjną, w jakiej znajdują się interlokutorzy oraz weryfikacja tego modelu w naturalnych sytuacjach rozmów podczas wizyty chorego w gabinecie lekarskim. Po ustaleniu modyfikacji w obrębie podstawowego wzoru rozmowy lekarza z pacjentem, zostaną zbadanie strategie konwersacyjne stosowane podczas tych rozmów. Wskazane zostaną akty mowy realizujące poszczególne strategie konwersacyjne (strategie informacyjnoweryfikacyjne, strategie aksjologiczno-emotywne, strategie behawioralne, strategie metadyskursywne) ${ }^{26}$.

Przyjęte zostanie pojęcie prototypu, zgodnie z którym model gatunku obejmuje cechy wyraziste, zlokalizowane się w centrum kategorii

\footnotetext{
${ }^{26}$ A. Awdiejew, Gramatyka interakcji werbalnej, Kraków, s. 73- 86.
} 
Michał Chojnowski - Standardowe i niestandardowe...

oraz cechy marginalne, znajdujące się na peryferiach ${ }^{27}$. Prototypowy model $w$ ujęciu przyjętym przez autora ma dwa znaczenia. $Z$ jednej strony model prototypowy interakcji lekarz - pacjent to model „podręcznikowy” przyjęty w publikacjach wskazujących wzorcową komunikację lekarza $\mathrm{z}$ pacjentem. Jednak badania pilotażowe w oparciu w autentyczny materiał pozyskany podczas nagrań rozmów lekarzy z pacjentami wskazały znaczne odstępstwa od tego modelu. Zostaną więc zbadane odstępstwa od wzorcowego modelu z uwzględnieniem występowania poszczególnych elementów w rozmowie, stosowanych przez rozmówców strategii konwersacyjnych oraz aktów mowy realizujących te strategie. Na tej podstawie zostanie sformułowane pojęcie prototypu na podstawie najczęściej stosowanych strategii konwersacyjnych poprzez poszczególne akty mowy.

\section{Charakterystyka materiału badawczego}

Analiza komunikacji lekarza z pacjentem oparta na zbieraniu autentycznego materiału, jego transkrypcji i interpretacji, będzie w stanie pokazać normatywne podstawy oceny komunikacji. Dzięki takiej analizie możliwe będzie sprawdzenie przydatności strategii konwersacyjnych w danym kontekście instytucjonalnym, a na tej podstawie zaproponowanie sposobów postępowania w kontekście komunikowania się lekarza z pacjentem, w tym propozycji szkoleń w tym zakresie, a także studiów podyplomowych dla lekarzy z zakresu komunikowania się lekarza z pacjentem. Zarejestrowane autentyczne rozmowy lekarza z pacjentem będą zapisywane w plikach wordowskich z przyjęciem zapisu ortograficznego, jednak bez znaków interpunkcyjnych, gdyż zaznaczane będą pauzy dłuższe, pauzy krótsze, znak zapytania dla oznaczenia intonacji pytającej i wykrzyknik dla zaznaczenia siły

27 E. Rosch, Human Categorization, [w:] Studies in Cross-Cultural Psychology, W. Warren (red.), London 1977, s. 1-49, [za:] B. Witosz, Opis w prozie narracyjnej na tle innych odmian deskrypcji. Katowice 1997, s. 38. 
głosu. Nie będzie stosowany zapis fonetyczny ani transkrypcja ${ }^{28}$. Zarejestrowane rozmowy zostaną zapisane w elektronicznych plikach tekstowych i zgrupowane tematycznie. Podany zostanie temat rozmowy, po czym zaznaczone zostaną numery rozmów dotyczące wymienionego tematu. Następnie zostaną scharakteryzowani rozmówcy oraz wskazany czas rozmowy.

\section{Opis metody badawczej}

Proponowane badania wpisują się w badania nad polskim językiem mówionym, które są w Polsce przeprowadzane poprzez analizę aktów mowy w tekstach mówionych, badania kryteriów tekstualności, mechanizmu spójności tych tekstów, a także typologii odmian polszczyzny mówionej29. Przyjęty w projekcie model analizy aktów mowy wywodzi się z prac J. L. Austina i J. R. Searle'a ${ }^{30}$, teorii genrów mowy A. Wierzbickiej31 oraz teorii A. Awdiejewa ${ }^{32}$. Po dokonaniu charakterystyki podstawowych pojęć stosowanych w pracy, analizie krytycznej literatury przedmiotu, omówione zostaną poszczególne akty mowy $\mathrm{w}$ wypowiedziach interlokutorów $\mathrm{z}$ uwzględnieniem charakterystyki sytuacji nadawczo-odbiorczej oraz charakteru par przylegających. W analizie zostanie również uwzględniony nurt badań seman-

\footnotetext{
${ }^{28} \mathrm{Nie}$ jest to zgodne z normą poprawnościową wówczas, gdy w cytowanych wypowiedziach pojawiałyby się błędy językowe.

${ }^{29}$ K. Pisarkowa, O spójności tekstu mówionego, [w:] Tekst i język. Problemy semantyczne, M. R. Mayenowa (red.), Wrocław 1974, s. 41-71; Tejże, Składnia rozmowy telefonicznej, Wrocław 1981; T. Skubalanka (red.), Studia nad składniq polszczyzny mówionej, Wrocław 1978; A. Wilkoń, Typologia odmian językowych współczesnej polszczyzny, Katowice 1987/2000; U. Żydek-Bednarczuk, Struktura tekstu rozmowy potocznej, Katowice 1994; B. Boniecka, Lingwistyka tekstu. Teoria i praktyka, Lublin 1999; M. Kita, Porozmawiajmy o rozmowie. Lingwistyczne aspekty dialogu, Katowice 2003.

${ }^{30}$ J. L. Austin, How to Do Things with Words. London 1962; Tegoż: Mówienie i poznawanie: rozprawy i wykłady filozoficzne. Warszawa 1993.

31 A. Wierzbicka, Genry mowy, [w:] Tekst i zdanie, T. Dobrzyńska, E. Janus (red.), Wrocław 1983, s. 130-137.

32 A. Awdiejew, Gramatyka..., dz. cyt., s. 25-34.
} 
Michał Chojnowski - Standardowe i niestandardowe...

tycznych, wprowadzony i stosowany przez Annę Wierzbicką z wyszczególnieniem metod eksplikowania znaczeń wyrażeń językowych.

Należy zatem najpierw dokonać przeglądu wybranych koncepcji klasyfikacji aktów mowy (Johna L. Austina i Johna R. Searle’a, D. Wunderlicha, Renaty Grzegorczykowej, Elżbiety Tabakowskiej, Aleksandra Awdiejewa i Zbigniewa Nęckiego, Karla L. Bühlera, Aleksandra Awdiejewa i Elżbiety Laskowskiej). Zgodnie z teorią aktów mowy, stworzoną przez Johna L. Austina i rozwijaną przez jego kontynuatorów, pragmatyka jest nauka badającą użycia języka w celu osiągnięcia zamierzonych efektów. Teoria aktów mowy opiera się na założeniu, iż zachowanie językowe jest działaniem, w którym wykonywane są różne akty mowy, oprócz czysto fizjologicznych lub fizycznych aktów wytwarzania wypowiedzi-sygnałów ${ }^{33}$. W projekcie zostaną zaprezentowane klasyfikacje aktów mowy Johna L. Austina, Johna R. Searle’a, Dietera Wunderlicha, koncepcja strategii konwersacyjnych według gramatyki komunikacyjnej, koncepcja Renaty Grzegorczykowej, kognitywna klasyfikacja aktów mownych Elżbiety Tabakowskiej, typologia pragmatyczno-kontekstowa Aleksego Awdiejewa i Zbigniewa Nęckiego, Karla Bühlera, teoria implikatur konwersacyjnych Paula H. Grice'a oraz typologia aktów mowy w oparciu o klasyfikację Aleksandra Awdiejewa i Elżbiety Laskowskiej ${ }^{34}$. W oparciu o klasyfikację Awdiejewa i Laskowskiej, wyróżnia się trzy typy aktów mowy: akty mowy informacyjno-weryfikacyjne, akty mowy wartościujące (emotywno-oceniające) oraz akty działania. Akty mowy informacyjno-weryfikacyjne zawierają akty powiadamiania, akty pytające oraz modalne. Akty działania są aktami nakłaniającymi oraz aktami zobowiązania. Akty powiadamiania są oznajmieniami, potwierdzeniami i zaprzeczeniami. Oznajmienie zostaje sformułowane $\mathrm{z}$ inicjatywy nadawcy, natomiast zaprzeczenia są reakcjami na pytanie odbiorcy, na jego sąd moralny lub asertywny. Akty pytające podzielić można na pytania i dopytania. To właśnie ta

\footnotetext{
33 J. Lyons, Semantyka, t. I, Warszawa 1989, s. 102.

${ }^{34}$ E. Laskowska, Dyskurs parlamentarny w ujęciu komunikacyjnym, Bydgoszcz 2004.
} 
grupa aktów w badaniach będzie miała znaczenie szczególne. Na podstawie klasyfikacji pytań $\mathrm{w}$ języku polskich zostaną podzielone pytania zarówno te, które są zadawane przez lekarza, jak i pytania zadawane przez pacjenta. Pytanie jest bardzo ważnym aktem mowy, który pełni ważną funkcję we wszystkich sekwencjach rozmowy lekarza z pacjentem. Poprzez zadanie pytania, nadawca chce uzyskać informację i powoduje powstanie aktu mowy - odpowiedzi. Pytania otwarte wymagają od osoby odpowiadającej opisu swojego stanowiska, poglądu, sytuacji, mogą być stosowane na początku rozmowy w celu zbadania problemu, przy zmianie tematu, kiedy tematem rozmowy są problemy trudne i drażliwe (Jak do tego doszło? Jak się pan czuje? Proszę, niech pan powie coś o swojej rodzinie; Co pani robi gdy odczuwa pani ból? Pytania zamknięte stawia się w dalszych etapach rozmowy (Czy czuje się pan dobrze? Czy ma pan żonę? Czy brał pan środki przeciwbólowe?) Dopytania stosuje się, gdy odpowiedzi pacjenta są krótkie lub gdy lekarz nie uzyskał informacji, które są niezbędne do postawienia diagnozy, a także przy omawianiu problemów trudnych i po zadaniu pytań otwartych (Czy mógłby Pan bliżej wyjaśnić...? Czy mógłby mi Pan coś bliżej powiedzieć na temat...?) A więc np. wśród strategii behawioralnych realizowanych poprzez prośbę wskazane zostaną środki językowe realizowane w ramach działań powitalnych, zachęty skierowanej do pacjenta w celu zajęcia miejsca, zachęty do przedstawienia problemu oraz deklarowania przez lekarza zbadania pacjenta.

Strategia konwersacyjna jest rozumiana jako świadomie kierowany przez nadawcę i odbiorcę spójny ciąg aktów mowy, za pomocą którego interlokutorzy dążą do osiągnięcia akceptowanego celu komunikacyjnego ${ }^{35}$. Chociaż nie jesteśmy $\mathrm{w}$ stanie przewidzieć zachowań werbalnych, ani też działań, które one za sobą pociągają, możemy wypracować pewne schematy działań werbalnych i zachowań i na ich podstawie prognozować stosowania strategii konwersacyjnych. Strategie te opierają się na ogólnych zasadach: zasadzie kooperacji

${ }^{35}$ A. Awdiejew, Strategie konwersacyjne (próba typologii), „Socjolingwistyka” 1991, nr 11, s. 8. 
Michał Chojnowski - Standardowe i niestandardowe...

H. P. Grice'a ${ }^{36}$ w ramach kategorii ilości, jakości, stosunku i sposobu i zasadzie grzeczności. Zasada konwersacji: Wnoś swój wkład do konwersacji tak, jak tego $w$ danym jej stadium wymaga przyjęty cel czy kierunek wymiany słów, w której bierzesz udział37, opiera się na trzech maksymach: maksymie jakości (nie mów tego, co uważasz za nieprawdziwe lub nieudowodnione); maksymie ilości (przekaż tyle informacji, ile trzeba dla osiągnięcia celu); maksymie istotności (mów rzeczy związane $\mathrm{z}$ aktualnym przebiegiem rozmowy); maksymie sposobu (bądź zrozumiały i taktowny wobec partnera, unikaj niejasności i niejednoznaczności) ${ }^{38}$. Analizując materiał badawczy, należy zwrócić uwagę, kiedy są łamane zasady konwersacji i jakie czynniki mają na to wpływ.

W aktach modalnych wyrażana jest pewność, stopień przekonania o prawdopodobieństwie, wyrażana nieokreśloność modalna, wątpliwości, przekonanie o wykluczeniu. Akty modalno-emotywne związane są z wyrażeniem nadziei oraz obawy. Ważne miejsce zajmują w komunikowaniu się lekarza z pacjentem akty mowy nakłaniające, nakłaniająco-zobowiązujące oraz akty zobowiązania. Należą one do aktów mowy zobowiązania. Celem badań będzie wyznaczenie, przy pomocy jakich środków językowych wyrażana jest w komunikowaniu się lekarza z pacjentem prośba, polecenie, żądanie, proponowanie, rada, odradzanie, ostrzeżenie, pozwolenie, odmowa polecenia, a więc akty mowy nakłaniające. Kolejną grupę będą stanowiły akty zobowiązania, tj. wyrażanie zamiaru podjęcia działania, obiecywanie, wyrażenie zgody na podjęcie działania oraz wyrażenie braku zgody na podjęcie dzia-

${ }^{36}$ H. P. Grice, Logic and Conversation, [w:] Syntax and Semantics. T. 3: Speech Acts, P. Cole, J. L. Morgan (red.), New York 1975, s. 41-58; tegoż, Logika a konwersacja, przekł. J. Wajszczuk, „Przegląd Humanistyczny” 1977, nr 6, s. 85-99; tegoż, Logika a konwersacja, przekł. B. Stanosz, [w:] B. Stanosz (red.), Język w świetle nauki, Warszawa 1980, s. 91-114; tegoż, Presupposition and Conversational Implicature, [w:] Radical Pragmatics, P. Cole (red.), New York 1981, s. 183-198.

37 H. P. Grice, Logika a konwersacja..., s. 96.

${ }^{38}$ H. P. Grice Ne uważał tej listy za zamkniętą, gdyż uznawał reguły o charakterze estetycznym, społecznym i moralnym. 
łania. Ostatnią grupę stanowią akty mowy nakłaniająco-zobowiązujące, tj. groźba oraz ostrzeżenie.

Z badań pilotażowych wynika, iż pytania zamknięte zadawane przez lekarzy różnią się od pytań zamkniętych pojawiających się w rozmowach potocznych. W rozmowach potocznych znacznie częściej zadaje się pytania zamknięte, które miałyby sugerować odpowiedzi pozytywne. Pytania zamknięte zadawane przez lekarza dotyczą tego, co jest nie w porządku ze zdrowiem pacjenta, a zatem sugerują negatywną ocenę. Okazało się także, iż - inaczej, niż we wzorcowych dialogach lekarza z pacjentem - często stosowana jest kategoria nieokreśloności, pacjenci stosują zaimki nieokreślone oraz niedokończone zdania (bo mnie / tutaj / tego / boli / tak mocno; takie coś / weszło mi w kolano/ nie mogę ruszyć nogą; brałam / brałam takie coś / no...). Często pojawia się kategoria depersonalizacji pacjenta (usiąść; oddychać głęboko; tak / trzymać jeszcze / trzymać / nie wypuszczać).

Poprzez analizę zgromadzonego materiału będzie można odpowiedzieć, jak wyrażane są akty mowy w komunikowaniu się lekarza z pacjentem. Punktem wyjścia będzie klasyfikacja materiału ze względu na typ strategii: informacyjno-weryfikacyjnej, aksjologiczno-emotywnej oraz behawioralnej. W obrębie każdej strategii scharakteryzowane zostaną realizujące się w jej ramach akty mowy oraz wskazane zostaną pojęciowe komponenty struktury, w których występuje omawiany akt mowy.

Analizując przebieg komunikacji lekarza z pacjentem zwrócona zostanie uwaga na używanie specjalistycznego języka przez lekarza. Pacjent mając świadomość, iż nie zna języka specjalistycznego, może się obawiać, że nie będzie mógł w sposób prawidłowy opisać swoich objawów, co powoduje kolejną obawę, iż lekarz postawić może błędną diagnozę. Zwrócona zostanie uwaga na różnice w sposobie przeprowadzania rozmowy lekarza rodzinnego $\mathrm{z}$ pacjentem, lekarza specjalisty, lekarza rozmawiającego z dzieckiem, z pacjentem dorosłym czy pacjentem w podeszłym wieku. Sam sposób przekazywania komunikatu o stanie zdrowia pacjenta różni się w zależności od zawartości 
Michał Chojnowski - Standardowe i niestandardowe...

treściowej komunikatu. Przekazywanie diagnozy grypy różni się od przekazywania diagnozy nowotworu, sposób przekazywania informacji pacjentowi - kobiecie jest inny niż pacjentowi - mężczyźnie, różni się w zależności od obecności lub braku obecności osób trzecich, np. studentów medycyny lub osoby towarzyszącej pacjentowi. Inaczej lekarz będzie formułował komunikaty skierowane do pacjentów, których widzi po raz pierwszy, a inaczej do znanych mu pacjentów.

\section{Zakończenie}

R. E. Lankamp wymienia „język komunikacji lekarzy z pacjentami” wśród innych typów „języka medycyny”, tj. języka kształcenia medycznego, języka zawodu medycznego, języka dziennikarstwa medycznego i technicznego języka medycznego ${ }^{39}$. Komunikowanie się lekarza z pacjentem należałoby zatem umieścić na szerszym tle „języka medycyny", ujmując także - w dalszej perspektywie - badania innych typów „języka medycyny” 40 . Jeśli natomiast wyniki badań miałyby być przełożone na poprawę komunikacji lekarza z pacjentem, niezbędne byłyby badania interdyscyplinarne $\mathrm{z}$ lingwistyki, socjologii, psychologii i oczywiście samej medycyny. Autor artykułu wyraża jednak nadzieję, iż proponowany projekt wskaże prototypowe i mniej prototypowe, aż do peryferyjnych, zachowania językowe w sytuacji komunikowania się lekarza $\mathrm{z}$ pacjentem. W początkowym okresie zainteresowania lingwistyki tym obszarem, zwracano uwagę na powtarzalność i reprodukowalność schematu organizacyjnego rozmowy lekarza z pacjentem, a proponowany model interakcji nazywano idealnym ${ }^{41}$. Badanie realnych sytuacji komunikacyjnych z uwzględnieniem kategorii prag-

39 R. E. Lankamp, Study on the Effect of Terminology of L2 Language Comprehension. Should Specialist Terms in Medical Texts be Avoided?, Amsterdam 1989, s. 21-22.

40 Por. np. artykuł M. Górnicz, Odmienności formalno-funkcjonalne wykładników dyskursu asekuracyjnego $w$ opisach wyników badań diagnostycznych $w$ medycynie, „Komunikacja Specjalistyczna” 2009, nr 2, s. 93-98.

41 P. ten Have, The consultation as a genre, [w:] Text ant Talk as Social Practice, B. Torode (red.) Dordrecht/Providence 1989, s. 115-135. 
matycznych konstytuujących tę sytuację, doboru składników treściowych, ich językowej realizacji, tj. wskazania strategii konwersacyjnych z uwzględnieniem stosowanych aktów mowy, wskazałoby, na ile ten typ interakcji odbiega od przyjętej konwencji z cechami profesjonalności i oficjalności po stronie lekarza oraz przygotowaniem pacjenta do konsultacji.

Wypadkowa koncepcji podstawowego wzoru rozmowy lekarza $\mathrm{z}$ pacjentem, rodzajów konsultacji lekarskich $\mathrm{w}$ ramach gatunku, (tj. wywiad i rozmowa potoczna, rozmowa terapeutyczna, rozmowa z klientem, opowiadanie o problemach, dyskusja), stosowanych strategii konwersacyjnych ze wskazaniem i charakterystyką stosowanych aktów mowy przez lekarza oraz pacjenta, z uwzględnieniem zmiennych wpływających na kształt konsultacji (wiek lekarza i pacjenta, płeć, konsultacje z lekarzem pierwszego kontaktu oraz ze specjalistą, specjalizacja lekarza, częstość kontaktów, obecność osób trzecich podczas rozmowy, faza konsultacji, miejsce konsultacji) ukształtuje obraz językowy komunikowania się lekarza z pacjentem w drugiej dekadzie XXI wieku i wskaże warunki skuteczności tej komunikacji wpływające na proces leczenia.

\section{Bibliografia:}

Austin J. L., How to Do Things with Words, Harvard University Press, London 1962.

Austin J. L., Mówienie i poznawanie: rozprawy i wykłady filozoficzne, PWN, Warszawa 1993.

Awdiejew A., Gramatyka interakcji werbalnej, Wydawnictwo Uniwersytetu Jagiellońskiego, Kraków 2004.

Awdiejew A., Strategie konwersacyjne (próba typologii), „Socjolingwistyka” 1991, t. XI.

Barański J., Waszyński E., Steciwko A. (red.), Komunikowanie się lekarza z pacjentem, Wydawnictwo Astrum, Wrocław 2000.

Boniecka B., Lingwistyka tekstu. Teoria i praktyka, Wydawnictwo Uniwersytetu M. Curie-Skłodowskiej, Lublin 1999. 
Michał Chojnowski - Standardowe i niestandardowe...

Boniecka B., Niestandardowe zachowania językowe lekarzy i pacjentów, „Poznańskie Spotkania Językoznawcze” 2004, Tom XIII.

Clarke G., Hall R., Rosencrance G., Physician - Patient Relations: No More Models, „American Journal of Bioethics” 2004, nr 2.

Cordella M., The Dynamic Consultation: A Discourse Analytical Study of Doctor - Patient Communication, John Benjamins, Amsterdam-Philadelphia 2004.

Emanuel E. J., Emanuel L. L., Four models of physician - patient relationship, „Journal American Medical Association” 1992, nr 16.

Enelow A. J., Swisher S. N., Interviewing and patient care,. Oxford University, New York 1986.

Freidson E., Profession of Medicine: A Study of the Sociology of Applied Knowledge, Harper and Row, New York 1970.

Gordon T., Edwards W. S., Rozmawiać z pacjentem: podręcznik doskonalenia umiejętności komunikacyjnych i budowania partnerskich relacji, Wyd. SWPS Academica, Warszawa 2009.

Górnicz M., Odmienności formalno-funkcjonalne wykładników dyskursu asekuracyjnego w opisach wyników badań diagnostycznych $w$ medycynie, „Komunikacja Specjalistyczna” 2009, nr 2.

Grabowski P., Lutczyn E., Jak rozmawiać z lekarzem. Wyd. Madipage, Warszawa 2012.

Grice H. P., Logic and Conversation, [w:] Syntax and Semantics. T. 3: Speech Acts, P. Cole, J. L. Morgan (red.), Academic Press, New York 1975.

Grice H. P., Logika a konwersacja, przekł. B. Stanosz, [w:] Język w świetle nauki, B. Stanosz (red.) Warszawa 1980.

Grice H. P., Logika a konwersacja. Przekł. J. Wajszczuk, „Przegląd Humanistyczny" 1977, nr 6.

Grice H. P., Presupposition and Conversational Implicature, [w:] Radical Pragmatics, P. Cole (red.), Academic Press, New York 1981.

H. Waitzkin, Doctor - patient communication: Clinical implications of social scientific research, „Journal of The American Medical Association” 1984, Vol. 252.

Have P. ten, The consultation as a genre, [w:] Text ant Talk as Social Practice, B. Torode (red.), Floris Publications, Dordrecht/Providence 1989.

Hebanowski M., Kliszcz J., Trzeciak B., Poradnik komunikowania się lekarza z pacjentem. Wyd. PZWL, Warszawa 1999.

Iluk J., Problemy tłumaczenia nazw medycznych na przykładzie języka polskiego i niemieckiego, „Glottodidactica” 1998, nr 26. 
Kita M. (red.), Porozmawiajmy o rozmowie. Lingwistyczne aspekty dialogu, Wydawnictwo Uniwersytetu Śląskiego, Katowice 2003.

Kokot U., Metody przekładu niemieckich nazw medycznych na język polski, Wydawnictwo Uniwersytetu Śląskiego, Katowice 2001.

Korsch B.M., Harding C., Świadomy pacjent. Jak mówić, żeby lekarz Cię słuchał, Wyd. Prószyński i S-ka, Warszawa 1999.

Labocha J., Tekst, wypowiedź, dyskurs, [w:] Styl a tekst, S. Gajda (red.), Wyd. Uniwersytetu Opolskiego, Opole 1996.

Lankamp R. E., Study on the Effect of Terminology of L2 Language Comprehension. Should Specialist Terms in Medical Texts be Avoided?, Rodopi, Amsterdam 1989.

Laskowska E., Dyskurs parlamentarny w ujęciu komunikacyjnym, Wydawnictwo Akademii Bydgoskiej im. Kazimierza Wielkiego, Bydgoszcz 2004.

Lyons J., Semantyka, t. I, PWN, Warszawa 1989.

Markowski A., Kultura języka w porozumiewaniu się lekarza z pacjentem, [w:] Porozumienie z pacjentem. Relacje i komunikacja, J. Doroszewski, M. Kulus, A. Markowski (red.), Wyd. Wolters Kluwer, Warszawa 2014.

Mayerscough P. R., Ford M., Jak rozmawiać z pacjentem, Gdańskie Wydawnictwo Psychologiczne, Gdańsk 2002.

Mishler E. G., The Discource of Medicine: Dialectics of Medical Interviews. Albex, Norwood 1984.

Ostrowska A., Zachowania zdrowotne Polaków na poczq̨tku XXI wieku [w:] Polska początku XXI wieku. Przemiany kulturowe i cywilizacyjne, K. Frysztacki, P. Sztompka (red.), Wydawnictwo PAN, Warszawa 2012.

Parsons T., Social Structure and Personality, Free Press, New York 1964.

Parsons T., The Social System, Routlege, London 1951.

Pendleton D., Hasler J. (red.), Doctor-patient communication, Academic Press, New York 1983.

Pisarkowa K., O spójności tekstu mówionego, [w:] Tekst i język. Problemy semantyczne, M. R. Mayenowa (red.), Zakład Narodowy im. Ossolińskich, Wrocław 1974.

Pisarkowa K., Składnia rozmowy telefonicznej, Zakład Narodowy im. Ossolińskich, Wrocław 1981.

Prokop I., Aspekty analizy pragmalingwistycznej, Wydawnictwo Naukowe Uniwersytetu im. Adama Mickiewicza, Poznań 2010. 
Michał Chojnowski - Standardowe i niestandardowe...

Rosch E., Human Categorization, [w:] Studies in Cross-Cultural Psychology, W. Warren (red.), Academic Press, London 1977.

Skubalanka T. (red.), Studia nad składniq polszczyzny mówionej, Zakład Narodowy im. Ossolińskich, Wrocław 1978.

Starzec A., Charakterystyka genologiczna i stylistyczna ulotki medycznej, [w:] Język a komunikacja 17: Język polski XXI wieku: analizy, oceny, perspektywy, G. Szpila (red.), Wyd. Krakowskie Towarzystwo Popularyzowania Wiedzy i Komunikacji Językowej „Tertium”, Kraków 2007.

Starzec A., Ulotka medyczna i jej przemiany, „Stylistyka” 2007, nr 16.

Stefaniak K., Władza i tożsamość w komunikacji lekarz - pacjent, Oficyna Wydawnicza ATUT - Wrocławskie Wydawnictwo Oświatowe, Wrocław 2011.

Szasz T., Hollender M. H., A contribution to the philosophy of medicine: the basic models of the doctor - patient relationship, „Archives of Internal Medicine" 1956, nr 97.

Titkow A., Zachowania zwiqzane ze zdrowiem i chorobq jako element wiedzy o społeczeństwie, [w:] Socjologia medycyny. Podejmowane problemy, kategorie analizy, A. Ostrowska (red.), Warszawa 2009.

Waitzkin H., A critical theory of medical discourse. Ideology, social control and the processing of social context in medical encounters, „Journal of Health and Social Behaviour" 1989, nr 30.

Wasilewski J., Retoryka dominacji, Wydawnictwo Trio, Warszawa 2006.

Wierzbicka A., Genry mowy, [w:] Tekst i zdanie, T. Dobrzyńska, E. Janus (red.), Wrocław 1983.

Wilkoń A., Typologia odmian językowych współczesnej polszczyzny, Wyd. Uniwersytetu Śląskiego, Katowice 1987/2000.

Witosz B., Opis w prozie narracyjnej na tle innych odmian deskrypcji, Wyd. Uniwersytetu Śląskiego, Katowice 1997.

Wojtak M., Strategie dyskursywne w pewnym typie tekstu dydaktycznego, [w:] Język w komunikacji, t. 3, G. Habrajska (red.), Łódź 2001.

Żydek-Bednarczuk U., Struktura tekstu rozmowy potocznej, Wyd. Uniwersytetu Śląskiego, Katowice 1994. 